European Journal of Logistics, Purchasing and Supply Chain Management

Vol.8 No.1, pp.15-18, March 2020

Published by ECRTD UK

ISSN 2054-0930 (Print), ISSN 2054-0949 (Online)

\title{
FORCE MAJEURE CLAUSE AND ITS APPLICABILITY IN THE CURRENT COVID- 2019 PANDEMIC IN THE PERSPECTIVE OF BANGLADESH
}

\author{
Mohammed Salah Uddin \\ Deputy Director (Senior Assistant Secretary) \\ Central Procurement Technical Unit \\ IMED, Ministry of Planning \\ Dhaka, Bangladesh
}

\begin{abstract}
With the rapid spreading of COVID-2019 in the whole world, it is crystal clear that this will certainly change the shape and nature of global supply chain. All the players both from the upstream and downstream will be seriously affected by the outbreak of COVID-2019. As modern global supply chain is remotely connected, the supply chain players come under the model form of contract. And force majeure clause is one of them-meaning a situation which is beyond the control of the contracting parties and none can be held responsible for performance of the contract. The scope and purview of the application offorce majeure clause vary across the world. Generally speaking, pandemic like COVID-2019 is treated as force majeure event. Any pandemic like COVID-2019 may create economic crisis and whether this economic crisis trigger the situation to call for and take recourse of force majeure clause is a debatable issues in the eye of courts of different countries. With the backdrop of this issue, it is high time we could revisit the contractual terms of conditions, assess and evaluate the degree and magnitude of the effect of the force majeure clause in the contract and go ahead with the settlement of the disputed claim in an amicable manner.
\end{abstract}

KEY WORDS: force majeure clause, performance of contract, contractual obligation, economic crisis, termination of contract.

\section{INTRODUCTION}

OECD recently said that COVID-2019 would compel to revisit the concept of supply chain and estimated that the lockdown/shutdown/restrictions will directly affect sectors amounting to up to one third of GDP in the major economies. For each month of containment, there will be a loss of 2 percentage points in annual GDP growth.COVID-2019 pandemic has been changing the spectrum and applicability of the Force Majeure (FM) clause in the area of global supply chain horizon. The companies are struggling to meet obligations under contract. There may be some lawsuits for recognizing the economic crisis as the force majeure event. The basics of global supply chain has been changing with the outbreak of COVID-2019. It has disrupted the flow of supply chain in both upstream and downstream. Some of the organizations, for example, International Chamber of Commerce (ICC), Paris, have taken initiatives to update the model form of contracts incorporating the pandemic like COVID-2019. 
European Journal of Logistics, Purchasing and Supply Chain Management

Vol.8 No.1, pp.15-18, March 2020

Published by ECRTD UK

ISSN 2054-0930 (Print), ISSN 2054-0949 (Online)

Now, we will explore the scope and extent of the Force Majeure (FM) clause in the context of both national and international perspectives. In general, Force Majeure (FM) clause (French for "superior force") is a condition in the commercial contract which relieves the parties from discharging their contractual obligations in case of certain events/circumstances beyond control. Section 56 of Contract Act-1872 states the scope of doctrine of frustration of contract. In illustration (d) of section 56 illustrates that-“A contracts to take in cargo for B at a foreign port. A's Government afterwards declares war against the country in which the port is situated. The contract becomes void when war is declared". Section 12 of the Bangladesh Labour Act-2006 states that (1) "An employer may, at any time, if necessary in the event of fire, sudden catastrophe, breakdown of machinery, stoppage of power supply, epidemics, wide spread riots or any other cause beyond his control, stop any section or sections of his establishment, wholly or partly, for such period as the cause for such stoppage continues to exist [Stoppage of work]. General Terms and Conditions of World Trade Organization (WTO) which shall apply to all contracts state that "In the event of force majeure or other situations that lie beyond the control of the Parties, are irresistible, do not result from their own negligence and prevent the normal performance of this contract, the Parties may agree to modify or temporarily suspend the supplies or services for which this contract provides."

However, clause 38-41 of General Conditions of Contract (GCC) of Standard Tender Document (STD), PG-4 (International) published by the Central Procurement Technical Unit (CPTU, IMED, Ministry of Planning defines the modality of application of Force Majeure(FM) clause. It states that FM means an exceptional event or circumstance: (a) which is beyond a Party's control; (b) which such party could not reasonably have provided against before entering into the contract; (c) which, having arisen, such party could not reasonably have avoided or overcome; and (d) which is not substantially attributable to the other party. Subject to the fulfilment of the above four conditions the following events may be included as FM: war, hostilities (whether war be declared or not), invasion, act of foreign enemies; rebellion, terrorism, sabotage by persons other than the contractor's personnel, revolution, insurrection, military or usurped power, or civil war; riot, commotion, disorder, strike or lockout by persons other than the contractor's personnel; munitions of war, explosive materials, ionising radiation or contamination by radio-activity, except as may be attributable to the contractor's use of such munitions, explosives, radiation or radio-activity, and natural catastrophes such as cyclone, hurricane, typhoon, tsunami, storm surge, floods, earthquake, landslides, fires, epidemics, quarantine restrictions, or volcanic activity; freight embargoes; acts of the Government in its sovereign capacity. Standard Tender Document(STD), PG-4 (International) also states that if a party is or will be prevented from performing its substantial obligations under the contract by FM, then it shall give notice to the other party of the event or circumstances constituting the FM and shall specify the obligations, the performance of which is or will be prevented. The notice shall be given within 14 days after the party became aware, or should have become aware, of the relevant event or circumstance constituting FM. The party shall, having given notice, be excused performance of its obligations for so long as such FM prevents it from performing them. Notwithstanding any other provision of this clause, FM shall not apply to obligations of either party to make payments to the other party under the contract. 
Vol.8 No.1, pp.15-18, March 2020

Published by ECRTD UK

ISSN 2054-0930 (Print), ISSN 2054-0949 (Online)

The consequences of the application of FM clause is that the supplier shall not be liable for forfeiture of its Performance Security, liquidated damages, or termination for default if and to the extent that it's delay in performance or other failure to perform its obligations under the contract (GCC 41.1). The purchaser may suspend the delivery or contract implementation, wholly or partly, by written order for a certain period of time, as it deems necessary due to force majeure as defined in the contract (GCC 41.2). With the outbreak of COVID-2019 it is reasonably assumed that the companies may be faced with more difficulties than usual to fulfil the contractual obligation. We can cite the example of Ebola Virus which spread across the Western Africa in 2015. Moroccan Government decided to postpone that year's "African Nations Cup" on the plea of the highest health hazard, citing it as "Force Majeure". But the court of arbitration for sports opined that outbreak of Ebola Virus cannot be considered as FM as it didn't make the hosting of tournament event impossible, but made it difficult and finally, Morocco was held responsible and fined $\$ 1$ million. Though considering the degree of intensity of COVID-2019, Tokyo Olympic 2020 is rescheduled to 23 July to 8 August 2021. COVID-2019 may affect the sports supply chain and FM can be an issue. Some may argue that the FM clause can't be invoked if it is not included in the contract. But in this case, a general principle of force majeure may be applied. The application of FM clause exposed by the outbreak of COVID-2019 can be called for and reasonably justified by the "United Nations Convention on Contracts for the International Sale of Goods (Vienna Convention)-1980".

It is a matter of great debate whether economic downturn or crisis leads to the situation to invoke FM clause. Different courts have given different ruling based on the prevailing situation. For example, In Great Lakes Gas Transmission, Ltd., v. Essar Steel Minnesota, LLC, case which lodged after 2007 world crisis, the court held that financial crisis didn't fall under the purview of FM clause and market forces were not considered in FM. In that suit, the court also held that the inability to obtain financing "was a foreseeable event". However, there are instances that the economic crisis constitutes the FM event. For example, in Hoosier Energy Rural electric Cooperative, Inc. v. John Hancock Life Ins. Co., the court held that the credit crisis facing the world's economies was unprecedented and was not foretold by the experts. Moreover, the application and magnitude of FM clause varies country to country. During debt crisis in the Greek, Greek parliament and European Commission recognized "Economic Crisis" as a cause giving rise to a prolonged FM event. Any event/circumstance can be recognized as FM based on the listings of the events or based on the setting of broad criteria, for example, "beyond the control of the both parties" or based on the combination of both. It is mentionable here that The China Council for the Promotion of International Trade (CCPIT) has already issued its first ever "FM certificate" to a company in China to address the loss accrued from the onset of COVID-2019.

It is high time we could revisit, evaluate and assess the extent of the existing contractual conditions with other international counterparts. In case of absence of explicit FM clause, Bangladesh may take recourse from provision of the "United Nations Convention on Contracts for the International Sale of Goods (Vienna Convention)-1980". In the last couple of years Bangladesh has entered into some large works and goods contract by means of competitive means. In this regard, all the Government Procuring Entities (PEs) may recognize the recrudescence of COVID-2019 as Force Majeure event which may, among other things, affect time extension of contract, adjustment of 
Vol.8 No.1, pp.15-18, March 2020

Published by ECRTD UK

ISSN 2054-0930 (Print), ISSN 2054-0949 (Online)

contract price and termination of contract. Moreover, EPB, BGMEA, BKMEA and other concerned agencies may come forward for exploring and evaluating this issues and a concerted effort may be taken under the auspices of the Government. Furthermore, it is very imperative that if one is planning to enter into any intentional contract at this moment, one may consider including COVID-2019 as FM event specifically.

Disclaimer: This article does not constitute any legal opinion or advice. It's only the personal opinion regarding the issue and is written only for academic purpose only. 